Citation: Saifitdinova, A, Koshel, E. Vishnevskaya, M., and Galkina, S. 2017. Celebrating the Jubilee of Elena Gaginskaya - the founder of the Lampbrushology School in Saint Petersburg University. Bio. Comm. 62(3): 159-164. https://doi.org/10.21638/11701/ spbu03.2017.301

Author's information: Alsu Saifitdinova, Ph.D., Director, orcid.org/0000-0002-1221 479X, Researcher ID: C-1104-2011, Elena Koshel, Ph.D., Postdoc, orcid.org/0000-00028957-5956, Researcher ID: L-7493-2016, Maria Vishnevskaya, Leading Specialist, orcid.org/0000-0002-2634-2610, Researcher ID: Q-8447-2017; Svetlana Galkina, Ph.D. Researcher, orcid.org/0000-0002-7034-2466, Researcher ID: J-2493-2013

Manuscript Editor: Prof. Em. Neil Jones, nstitute of Biological, Environmental and Rural Sciences, Aberystwyth University, Aberystwyth, U. K

Received: October 9, 2017.

Revised: November 15, 2017;

Accepted: November 15, 2017;

Copyright: (c) 2017 Saifitdinova et al. This is an open-access article distributed under the terms of the License Agreement with Saint Petersburg State University, which permits to the authors an unrestricted distribution and self-archiving free of charge.

Funding: No funding information provided.

Competing interests: The authors have declared that no competing interests exist.

\section{Celebrating the Jubilee of Elena Gaginskaya - the founder of the Lampbrushology School in Saint Petersburg University}

\section{Alsu Saifitdinova ${ }^{1}$, Elena Koshel ${ }^{2}$ Maria Vishnevskaya ${ }^{1}$, and Svetlana Galkina ${ }^{3}$}

${ }^{1}$ Chromas Research Resource Center, Saint Petersburg State University, Oranienbaumskoye sh. 2, 198504, Saint Petersburg, Russian Federation; saifitdinova@mail.ru

2 Department of Cytology and Histology, Saint Petersburg State University,

Universitetskaya nab. 7-9, 199034, Saint Petersburg, Russian Federation;

3 Department of Genetics and Biotechnology, Saint Petersburg State University,

Universitetskaya nab. 7-9, 199034, Saint Petersburg, Russian Federation

Address correspondence and requests for materials to Alsu Saifitdinova

\section{Abstract}

Elena Gaginskaya is an outstanding scientist, doctor of biological sciences, professor, international expert, creator of the first core facility at St. Petersburg State University, and the founder of the Lampbrushology Scientific School. She celebrates her 85th birthday this year. Students, colleagues and friends congratulate Elena with all their hearts on her jubilee, and mark their devotion to her with this publication.

Keywords: Jubilee, Elena Gaginskaya, lampbrush chromosomes

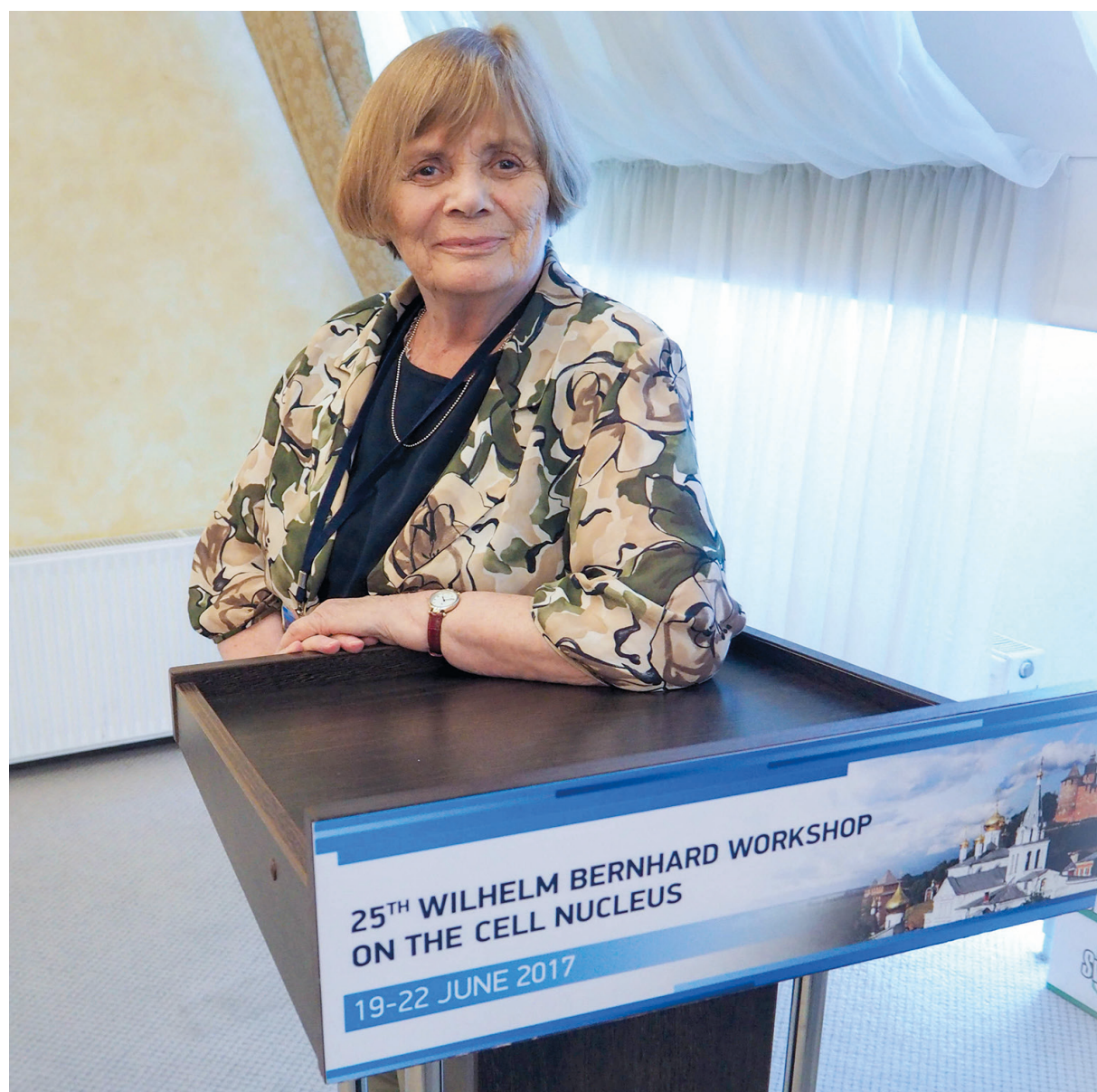

Fig. 1. Elena Gaginskaya, photographed in 2017 after her fabulous talk in N. Novgorod 


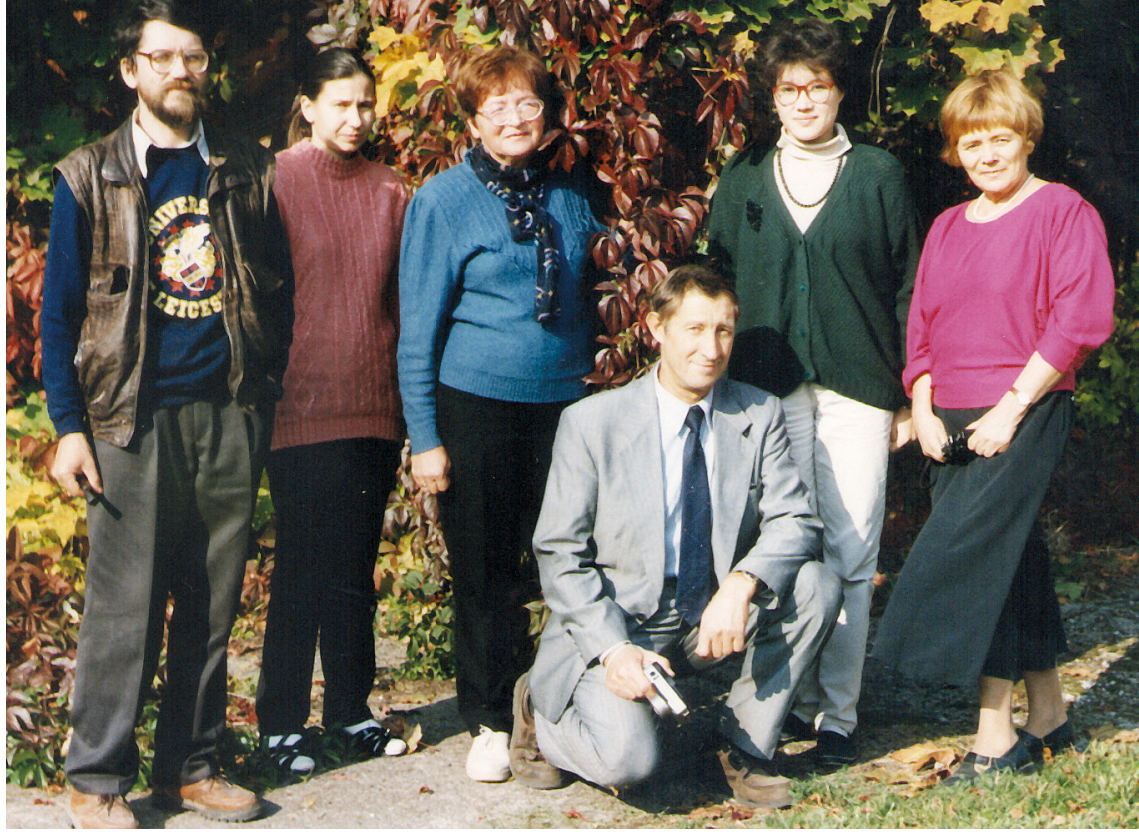

Fig. 2. The Laboratory of Chromosome Structure and Function in Biological Institute in 1999. A. V. Rodionov, S. E. Deryusheva, N. A. Lukina, D. V. Ossipov, A. F. Saifitdinova, E. R. Gaginskaya

Elena Gaginskaya was born on July 15, 1932, in Gorky (N. Novgorod), in the family of an artist. By the beginning of the World War Second, the family lived in Leningrad. Elena's father was killed at the front, and her mother was left with two children. During the blockade the family was evacuated, and Elena sometimes recalls the queues for bread. They returned to Leningrad only after the war. Life was not easy, but Elena often talks about her father's artist friends who took care of her family, and about her mother, who worked in a public library and did everything to give her children a good education. Creative people continue to surround Elena Gaginskaya.

Another characteristic feature of Elena is her unquenchable curiosity, which, combined with a love of nature, brought her to Leningrad University and for many years determined her fate. Her teacher and scientific advisor in her student years was the outstanding ornithologist Alexei Malchevsky. Elena likes to quote his statement that when working with people "human qualities" are the most important, because you can teach many things, but you cannot teach someone to be a person. Elena's scientific interests developed from faunistics and studies of bird migration to the study of cellular mechanisms of oogenesis and the structural and functional characteristics of the nucleus, and further to the fundamental problems of the evolution of genomes. Through all these years, she remained faithful to her alma mater, the Biological Institute of Leningrad University, and to Russian science, contributing not only to its development, but also to personnel training.

Forty-five years ago, immediately after the defense of her Ph.D., Elena started to manage the electron microscopy laboratory. It was a supporting unit that provided the operation of the equipment complex, which was used by specialists of different laboratories of the Biological Institute for their research. Elena gradually turned it into a research laboratory where students, postgraduates, and young scientists worked. Working on histological and ultrathin sections of ovaries, Elena and her students studied the cytological aspects of oogenesis in birds, identified a new class of structures formed in growing oocytes on chromosomes, and described a special intermediate type of oogenesis in birds characterized by the deactivation of ribosomal genes in the oocyte core. In the mid-80s, under the influence of the works of G. Callan, H. Macgregor and J. Gall,

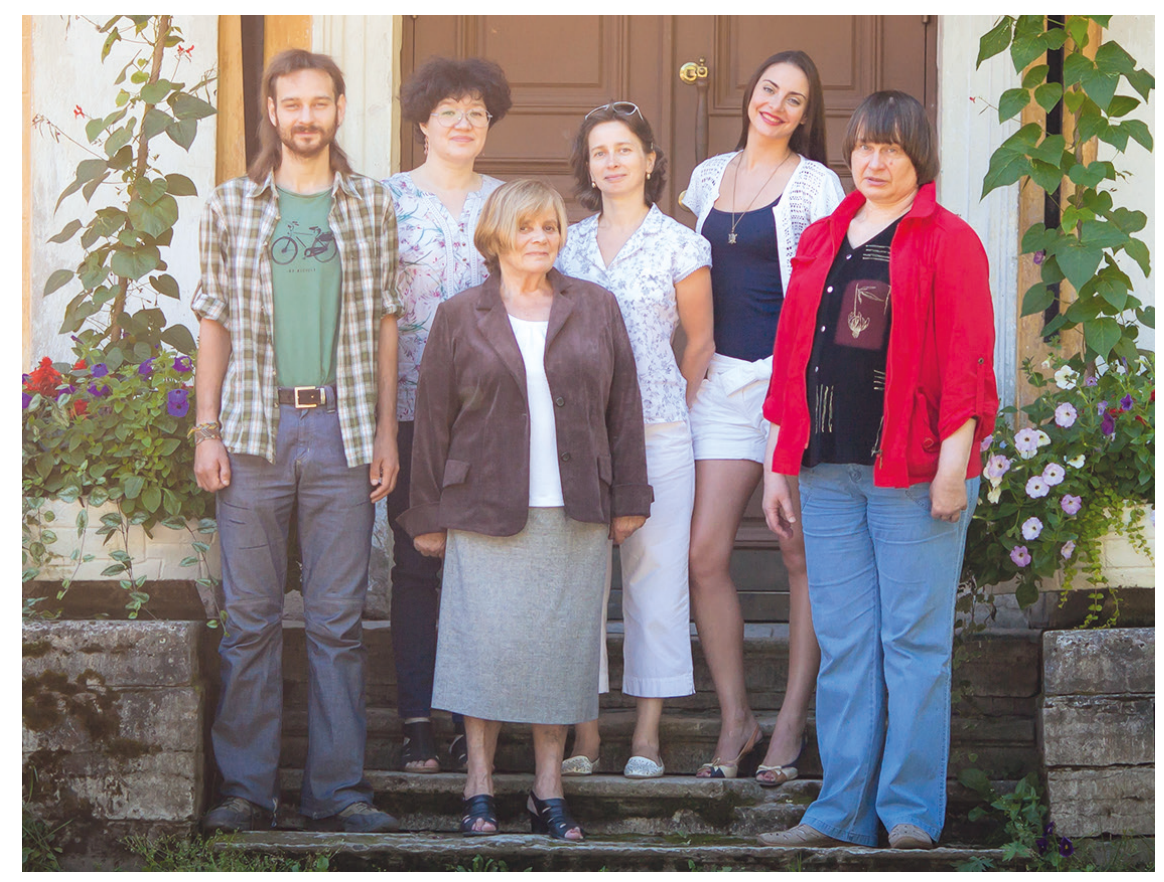

Fig. 3. The Laboratory of Chromosome Structure and Function in 2015. A. G. Dyomin, A. F. Saifitdinova, E. R. Gaginskaya, S. A. Galkina, E. I. Koshel, O. B. Lavrova 


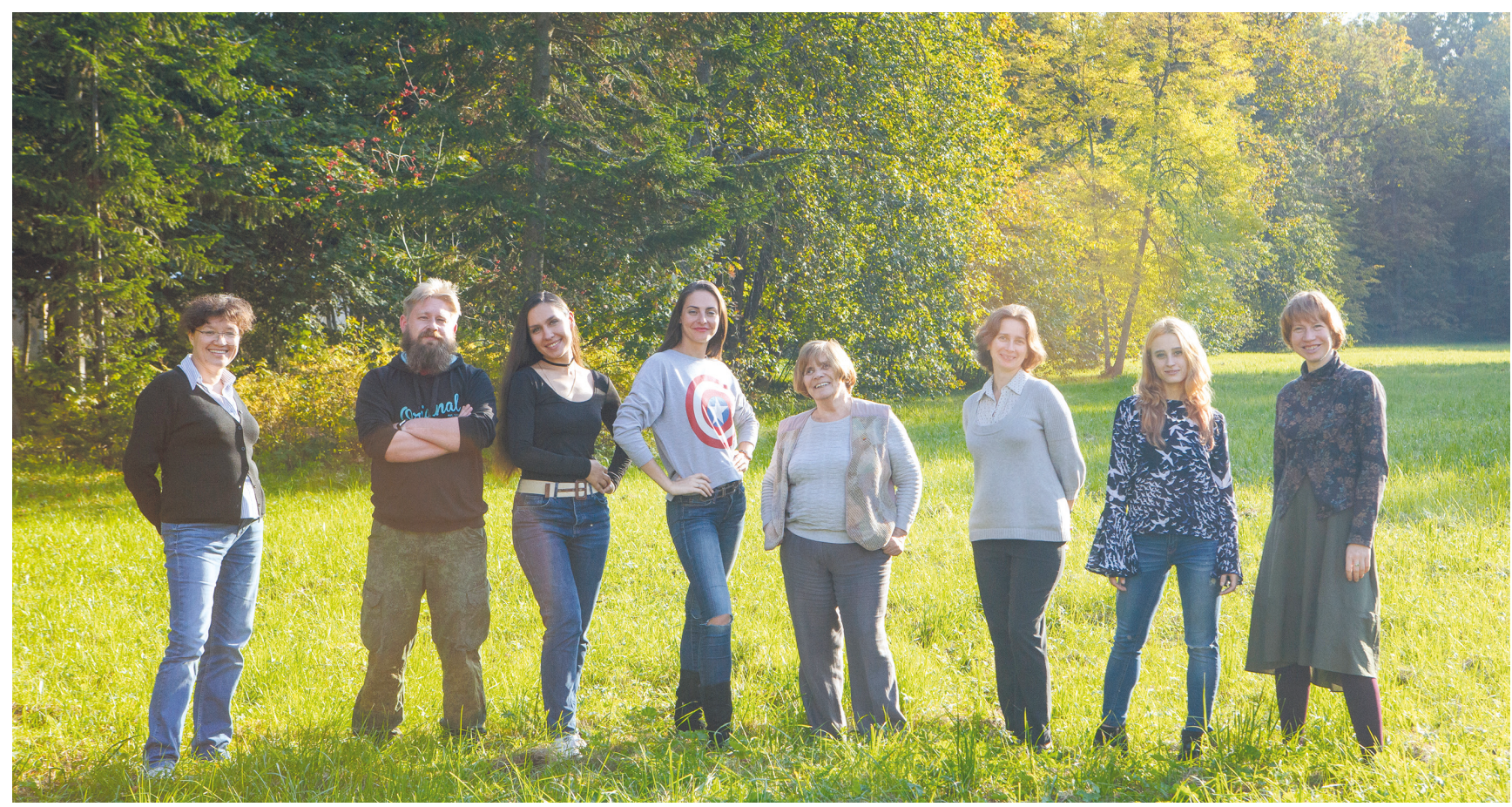

Fig. 4. The Laboratory of Chromosome Structure and Function and "Chromas" Core Facility staff in 2017. A. F. Saifitdinova, A. V. Radaev, A. G. Davidian, E. I. Koshel, E. R. Gaginskaya, S. A. Galkina, V. A. Volodkina, M. M. Kulak

a method for the extraction of lampbrush chromosomes from bird oocytes was first developed in the laboratory.

The development of this methodology opened up new and broad prospects for further research, so specialists from different countries turned to Elena and her staff with requests to conduct fine mapping of the studied sequences on bird chromosomes. Based on the success of lampbrush chromosome research, in 1986 the laboratory was renamed to the Laboratory of Chromosome Structure and Function, which is now widely known throughout the world for its achievements. The Russian school's research on giant transcriptionally active chromosomes was highly appreciated, and the Russian team headed by Professor Gaginskaya can objectively be considered the current leader in the field of lampbrushology for research in developmental and cell biology, cytogenetics and evolution.

In the last decade of the 20th century, which was a very difficult time for the country, the Laboratory of Chromosome Structure and Function continued making discoveries and publishing works in leading scientific journals. For a long time, the banner of the Russian Foundation for Fundamental Research included, along with a photograph of the radio telescope, an image of immunostained chaffinch lampbrush chromosome made in the laboratory of Elena Gaginskaya. Recognition provided an opportunity to receive grants and invest in the development of the laboratory. In 1997, for the first time at St. Petersburg State University, the Chromas Core Facility was created on the laboratory base. It helped many employees of the Biological Institute and other university departments, as well as staff of other academic institutions, to carry out high-level research. (In 2003, Chromas Core Facility was included in the network of Core Facilities of the Russian Federation; in 2010, it entered the network of St. Petersburg State University Core Facilities; and in 2014, it became a part of the Science Park of St. Petersburg State University, http:chromas.spbu.ru/.) Elena Gaginskaya directed the work of Chromas until 2015.

The leading scientific school, referred to as "The Phenomenon of Lampbrush Chromosomes: a Contribution to Development Biology, Cell Biology and Evolutionary Cytogenetics", under the guidance of Professor Elena Gaginskaya, has been supported for many years by the program of the President of the Russian Federation, and has given many scientists a start in scientific life. For many years, Gaginskaya's work has been focused on a comprehensive study of the phenomenon of lampbrush chromosomes and the use of lampbrush chromosomes of birds as a model object for analyzing the fundamental problems of the structure, functioning, regulation and evolution of the eukaryotic genome. Work on the organization and evolution of the nucleolus organizer, published in the last two years, opened a new direction for the development of school research and once again provided great opportunities to students and colleagues of Professor Gaginskaya. Those who have been lucky enough to communicate with Elena have a vivid impression of the charm of her personality. It should be noted 
that many people in Russia and abroad know and appreciate her, both inside and outside the realm of professional interaction.

For illustrative material, photos are taken from the archives of A.G.Davidyan, M.R. Kuleshin and A. F. Saifitdinova.

\section{Elena Gaginskaya's bibliography}

Noskov, G.A., Gaginskaya, E.R., Kamenev, V.A., Bolshakov K. V., and Haare, A. O. 1965. Migrations of birds in the eastern part of the Gulf of Finland. Reports of the Baltic Commission on the Study of Migratory Birds 3:1-28.

Gaginskaya, E. R., and Haare, A. O. 1968. Features of the spring and autumn passage of some birds in the area of Stary Peterhof. Vestnik Leningradskogo Gosudarstvennogo Universiteta, Series Biology 21:15-21.

Gaginskaya, E. R. 1969. Passage of passerine birds on the southern coast of the Gulf of Finland. Voprosi ekologii $i$ biocenologii 9:37-48.

Gaginskaya, E. R. and Gruzova, M. N. 1969. Features of oogenesis of finch. Tsitologiia 11(10):1241-1251.

Gaginskaya, E. R. 1972. Nuclear structures in oocytes of sexually mature birds. I. Behavior of chromosomes in the period of growth of the oocyte. Tsitologiia 14(4):426-432.

Gaginskaya, E. R. 1972. Nuclear structures in oocytes of sexually mature birds. II. Protein bodies and carious sphere. Tsitologiia 14(5):568-577.

Gaginskaya, E. R. 1972. Nuclear structures in oocytes of sexually mature birds. Abstract of the Candidate's Dissertation. LGU, 23 pp.

Gaginskaya, E. R. 1975. The problem of classification of types of oogenesis. Ontogenez 6(5):539-545.

Gaginskaya, E. R., and Gruzova, M. N. 1975. Revealing of amplified rDNA in oocytes of some insects and birds by hybridization of nucleic acids on preparations. Tsitologiia 17(10):1132-1137.

Chin, H., Kalinina, E. I., and Gaginskaya, E. R. 1979. Features of oogenesis of chicken. I. Extraphollicular period in the development of oocytes. Ontogenez 10(4):340-349.

Gaginskaya, E. R., and Chin, H. 1980. Features of oogenesis of chicken. II. Follicular period in the development of oocytes. Ontogenez 11(3):213-221.

Kalinina, E. I., and Gaginskaya, E. R. 1980. Preleptotene stage in the oogenesis of a domestic chicken. Tsitologiia 22(8):899-906.

Gaginskaya, E. R., and Kalinina, E. I. 1982. Preleptotene condensation of chromosomes. In: Biohimia, genetika, tsitologiia meyoza. Moskovskoye Obschestvo Ispytateley Prirody: Moscow. P. 97-102.

Gaginskaya, E. R., Dondua, A. K., Zavarzin, A. A., Raikov, I. B., and Studitski, A. B. 1982. Evolutionary Cell Morphology (book review). Tsitologiia 24(5):625-632.

Gaginskaya, E. R., Kasianov, V. L., and Kornienko, E. S. 1983. Features of oogenesis of the Far Eastern sea star Henricia sp.. Tsitologiia 23(2):135-140.

Kalinina, E. I., and Gaginskaya, E. R. 1983. Autoradiography and cytophotometric study of the pre-leptotene oocyte in a domestic chicken. Tsitologiia 25(12):1370-1378.

Tsvetkov, A. G., and Gaginskaya, E. R. 1983. The nuclear matrix of finch oocytes. Tsitologiia 25(6):649-654.

Gaginskaya, E. R. 1984. The morphology of the transcription of the lampbrushes of birds. Tsitologiia 26(9):1064-1065.

Kropotova, E. V., and Gaginskaya, E. R. 1984. Lampbrush chromosomes from oocytes of Japanese quail. Tsitologiia 26(10):1008-1015.
Gaginskaya, E. R., Kasianov, V. L., and Kogan, G. L. 1987. Amplification of ribosomal genes and the formation of extrachromosomal nucleoli in marine star oocytes. Tsitologiia 29(11):1235-1245.

Gaginskaya, E. R., Tsvetkov, A. G. 1988. Electron-microscopic study of chromatin structure in dispersed chicken lampbrushes chromosomes. Tsitologiia 30(2):142-150.

Gaginskaya, E. R., Kasyanov, V.L., and Kogan, G. L. 1988. Amplification of ribosomal genes and formation of extrachromosomal nucleoli in oocytes of starfish Henricia hayashi (Asteroidea: Echinasteridae). Cell Differentiation 23(1-2):53-60. https://doi.org/10.1016/00456039(88)90036-Xa

Tarantul, V. Z., Goltsov, V. A., Rodionov, A. V., Hutinaeva, M. A., Gaginskaya, E. R., and Gazaryan, G. K. 1989. Molecular and cytological analysis of clusters of moderate repeats of bird genomes. Molecularnaya Biologia 23(2):481-490.

Tarantul, V. Z., Rodionov, A. V., Makarova, I. V., Goltsov, V. A., Chelisheva, L. A., Hutinaeva, M. A., Gaginskaya, E. R., and Gazaryan, G. K. 1989. Molecular and cytological analysis of transcription of evolutionarily conservative moderately repeating sequences of vertebrate genomes. Tsitologiia 31(6):619-625

Rodionov, A. V., Chelisheva, L. A., Kropotova, E. V., and Gaginskaya E. R. 1989. Heterochromatic regions of chicken chromosomes and quail in mitosis and at the stage of lampbrush chromosomes. Tsitologiia 31(8):867-873.

Hutinaeva, M. A., Kropotova, E. V., and Gaginskaya, E. R. 1989. Functional morphology of pigeon lampbrush chromosomes. Tsitologiia 31(10):1185-1192.

Gaginskaya, E. R. 1989. Lampbrush chromosomes from amphibian oocytes. Tsitologiia 31(11): 1267-1291.

Gaginskaya, E. R. 1989. Functional morphology of chromosomes in oogenesis of birds. Abstract of the Doctor of Science Dissertation. Leningrad, $35 \mathrm{pp}$.

Chelisheva, L. A., Solovei, I. V., Rodionov, A. V, Yakovlev, A. F., and Gaginskaya, E. R. 1990. Lampbrush chromosomes of chicken. Cytological maps of macro-bivalents. Tsitologiia 32(4):303-316.

Solovei, I. V., Chelisheva, L.A., Rodionov, A. V., and Gaginskaya, E.R. 1990. Identification and structure of sexual bivalent in birds in the stage of lampbrush chromosomes. Tsitologiia 32(8):817-825. https://doi. org/10.1007/BF00710769

Rodionov, A. V., Myakoshina, Y.A., Solovei, I. V, Chelisheva, L. A, and Gaginskaya, E. R. 1992. Chiasmas on lampbrushes chromosomes of Gallus gallus domesticus: Cytogenetic study of recombination frequency and length of clutch groups. Russian Journal of Genetics 28(4):53-63.

Solovei, I., Gaginskaya, E., Allan T., and Macgregor, H. 1992. A novel structure associated with a lampbrush chromosome in the chicken Gallus domesticus. Journal of Cell Science 101:759-772.

Solovei, I., Gaginskaya, E., Hutchison, N., and Macgregor, H. 1993. Avian sex chromosomes in the lampbrush form: the ZW lampbrush bivalents from six species of bird. Chromosome Research 1(2):153-166. https://doi. org/10.1007/BF00710769

Solovei, I., Gaginskaya, E., and Macgregor, H. 1994. The arrangement and transcription of telomere DNA sequences at the ends of lampbrush chromosomes of birds. Chromosome Research 2(6):460-470. https://doi. org/10.1007/BF01552869

Gaginskaya, E. R., Macgregor, H. C., Rodionov, A. V., and Solovei, I. V. 1994. Lampbrush chromosomes in the growing oocytes of birds. Ontogenez 25(4):61-62.

Solovei, I., Macgregor, H., and Gaginskaya, E. 1995. Single stranded nucleic acid binding structures on chick- 
en lampbrush chromosomes. Journal of Cell Science 108(4):1391-1396.

Solovei, I., Macgregor, H., and Gaginskaya, E. 1995. Specifically terminal clusters of telomere DNA sequences are transcripted from C-rich strand on chicken lampbrush chromosomes. Chromosome Today 11:147-156.

Solovei, I., Joffe, B., Macgregor, H., and Gaginskaya, E. 1996. Transcription of a centromericaly localized highly repeated DNA in pigeon relates to sequence arrangement. Chromosome Research 4:475-483. https://doi. org/10.1007/BF02261722

Saifitdinova, A. F., Timofejeva, L. P., Zhurov, V. G., Andreeva, T. F., and Gaginskaya, E. R. 2000. A highly repeated FCP centromeric sequence from chaffinch (Fringilla coelebs) genome is revealed within interchromosomal connectives during mitosis. Tsitologiia 42(6):581-586.

Saifitdinova, A. F., Derjusheva, S. E., Malykh, A. G., Zhurov, V.G., Andreeva T. F., and Gaginskaya E. R. 2001. Centromeric tandem repeat from the chaffinch genome: isolation and molecular characterization. NRC Research Press. Genome 44(2):2001-2011. https://doi. org/10.1139/gen-44-1-96

Malykh, A. G., Zhurov, V.G., Saifitdinova, A.F., Deryusheva, S. E., and Gaginskaya, E. R. 2001. Structural and functional characterization of a centromeric highly repetitive DNA sequence of Fringilla coelebs L. (Aves: Passeriformes). Molecular Biology 35(3):331-335. https://doi. org/10.1023/A:1010458325021

Liangouzov, I.A., Derjusheva, S.E., Saifitdinova, A. F., Malykh, A. G., and Gaginskaya, E. R. 2002. Monomers of a satellite DNA sequence of chaffinch (Fringilla coelebs L., Aves: Passeriformes) contains short clusters of the TTAGGG repeat. Russian Journal of Genetics 38(12):13591364. https://doi.org/10.1023/A:1021679520236

Saifitdinova, A., Derjusheva, S., Krasikova, A., and Gaginskaya, E. 2003. Lampbrush chromosomes of the chaffinch (Fringilla coelebs L.). Chromosome Research 11(2):99-113 https://doi.org/10.1023/A:1022859713777

Derjusheva, S., Kurganova, A., Krasikova, A., Saifitdinova, A., Habermann, F., and Gaginskaya, E. 2003. Precise identification of chicken chromosomes in the lampbrush form using chromosome painting probes. Chromosome Research 11(6):749-757. https://doi.org/10.1023/ B:CHRO.0000005778.72909.4d

Deryusheva, S., Kurganova, A., Habermann, F., and Gaginskaya, E. R. 2004. High chromosome conservation detected by comparative chromosome painting in chicken, pigeon and passerine birds. Chromosome Research 12:715-723. https://doi.org/10.1023/ B:CHRO.0000045779.50641.00

Krasikova, A., Kulikova, T., Derjusheva, S., Saifitdinova, A., and Gaginskaya, E. R. 2004. Centromeric protein bodies on avian lampbrush chromosomes contain a protein detectable with an antibody against DNA topoisomerase II. Chromosoma 113:316-323. https://doi.org/10.1007/ s00412-004-0321-5

Krasikova, A., Barbero, J. L., and Gaginskaya, E. 2005. Cohesion proteins are present in centromere protein bodies associated with avian lampbrush chromosomes. Chromosome Research 13:675-685. https://doi.org/10.1007/ s10577-005-1005-6

Galkina, S., Deryusheva, S., Fillon, V., Vignal, A., Crooijmans, R., Groenen, M., Rodionov, A., and Gaginskaya, E. 2006. FISH on avian lampbrush chromosomes produces higher resolution gene mapping. Genetica 128(1-3):241-251. https://doi.org/10.1007/s10709-005-5776-7

Krasikova, A., Deryusheva, S., Galkina, S., Kurganova, A., Evteev, A., and Gaginskaya E. 2006. On the positions of centromeres in chicken lampbrush chromosomes. Chromosome Research 14(7):777-789. https://doi. org/10.1007/s10577-006-1085-y

Deryusheva, S., Krasikova, A., Kulikova, T., and Gaginskaya E. 2007. Tandem 41-bp repeats in chicken and Japanese quail genomes: FISH mapping and transcription analysis on lampbrush chromosomes. Chromosoma 116:519530. https://doi.org/10.1007/s00412-007-0117-5

Griffin, D. K., Robertson, L. B., Tempest, H. G., Vignal, A., FilIon, V., Crooijmans, R. P. M. A., Groenen, M. A. M., Deryusheva, S., Gaginskaya, E., Carré, W., Waddington, D., Talbot, R., Völker, M., Masabanda, J.S., and Burt D.W. 2008. Whole genome comparative studies between chicken and turkey and their implications for avian genome evolution. BMC Genomics 14(9):168-182. https:// doi.org/10.1186/1471-2164-9-168

Gaginskaya, E., Kulikova, T., and Krasikova, A. 2009. Avian lampbrush chromosomes: a powerful tool for exploration of genome expression. Cytogenetics and Genome Research 124(3-4):251-267. https://doi.org/10.1159/000218130

Krasikova, A., Daks, A., Zlotina, A., and Gaginskaya, E. 2009. Polymorphic heterochromatic segments in Japanese quail microchromosomes. Cytogenetics and Genome Research 126:148-155. https://doi.org/10.1159/000245914

Krasikova A., and Gaginskaya E. 2010. Organisation of centromere regions of chromosomes in the lampbrush phase. Tsitologiia 52(7):515-533.

Daks, A., Deryusheva, S., Krasikova, A., Zlotina, A., Gaginskaya, E. and Galkina, S. 2010. Lampbrush chromosomes of the Japanese quail (Coturnix coturnix japonica): A new version of cytogenetic maps. Russian Journal of Genetics 46(10):1178-1181. https://doi.org/10.1134/ S102279541010008X

Krasikova, A., Vasilevskaya, E., and Gaginskaya, E. 2010. Chicken lampbrush chromosomes: transcription of tandemly repetitive DNA sequences. Russian Journal of Genetics 46(10):1173-1177. https://doi.org/10.1134/ S1022795410100078

Zlotina, A., Galkina, S., Krasikova, A., Crooijmans, R.P., Groenen, M. A., Gaginskaya, E., and Deryusheva, S. 2010. Precise centromere positioning on chicken chromosome 3. Cytogenetics and Chromosome Research 129:310313. https://doi.org/10.1159/000314923

Khodyuchenko, T., Gaginskaya, E., and Krasikova, A. 2012. Non-canonical Cajal bodies form in the nucleus of late stage avian oocytes lacking functional nucleolus. Histochemistry and Cell Biology 138(1):57-73. https://doi. org/10.1007/s00418-012-0938-z

Zlotina, A., Galkina, S., Krasikova, A., Crooijmans, R.P., Groenen, M.A., Gaginskaya, E., and Deryusheva, S. 2012. Centromere positions in chicken and Japanese quail chromosomes: de novo centromere formation versus pericentric inversions. Chromosome Research 20(10):1017-1031. https://doi.org/10.1007/s10577-0129319-7

Stepakov, A., Galkina, S., Bogomaz, D., Gaginskaya, E., and Saifitdinova, A. 2015. Modified synthesis of 6-carboxyfluorescein (6-FAM): Application to probe labeling for conventional cytogenetics. British Journal of Applied Science and Technology 7(4):423-428. https://doi.org/10.9734/ BJAST/2015/15991

Saifitdinova, A. F., Galkina, S.A., Koshel, E. I., and Gaginskaya, E. R. 2016. The role of repetitive sequences in the evolution of sex chromosomes in birds. Tsitologiia 58:393-398.

Dyomin, A. G., Koshel, E. I., Kiselev, A. M., Saifitdinova, A. F., Galkina, S. A., Fukagawa, T., Kostareva, A. A., and Gaginskaya, E. R. 2016. Chicken rRNA gene cluster structure. 
PLOS ONE 11(6): e0157464. https://doi.org/10.1371/journal.pone.0157464

Koshel, E., Galkina, S., Saifitdinova, A., Dyomin, A., Deryusheva, S., and Gaginskaya E. 2016. Ribosomal RNA gene functioning in avian oogenesis. Cell and Tissue Research 366(3):533-542. https://doi.org/10.1007/s00441-016 2444-4

Koshel, E.I., Chelushkin, P.S., Melnikov, A.S., Serdobintsev, P.Yu., Stolbovaia, A. Yu., Saifitdinova, A. F., Shcheslavskiy, V. I., Chernyavskiy, O., Gaginskaya, E. R., Koshevoy, I. O., and Tunik, S. P. 2016. Lipophilic phosphorescent gold (I) clusters as selective probes for visualization of lipid droplets by two-photon microscopy. Journal of Photochemistry and Photobiology A: Chemistry 332:120133. https://doi.org/10.1016/j.jphotochem.2016.08.017

Kulikova, T., Chervyakova, D., Zlotina, A., Krasikova, A. and Gaginskaya, E. 2016. Giant poly(A)-rich RNP aggregates form at terminal regions of avian lampbrush chromosomes. Chromosoma 125(4):709-724. https://doi. org/10.1007/s00412-015-0563-4

Bellott, D.W., Skaletsky, H., Cho, T.J., Brown, L., Locke, D., Chen, N., Galkina, S., Pyntikova, T., Koutseva, N., Graves, T., Kremitzki, C., Warren, W. C., Clark, A. G., Gaginskaya, E., Wilson, R. K., Page, D. C. 2017. Avian W and mammalian $\mathrm{Y}$ chromosomes convergently retained dosage-sensitive regulators. Nature Genetics 49(3):387394. https://doi.org/10.1038/ng.3778

Galkina, S., Fillon, V., Saifitdinova, A., Daks, A., Kulak, M., Dyomin, A., Koshel, E., and Gaginskaya, E. R. 2017. Chicken Microchromosomes in the lampbrush phase: A cytogenetic description. Cytogenetic and Genome Research 152(1):46-54. https://doi.org/10.1159/000475563

Dyomin, A., Volodkina, V., Koshel, E., Galkina, S., Saifitdinova, A., and Gaginskaya, E. 2017. Evolution of ribosomal internal transcribed spacers in Deuterostomia. Molecular Phylogenetics and Evolution 116:87-96. https://doi. org/10.1016/j.ympev.2017.08.015

Davidian, A. G., Koshel, E. I., Lavrova, O. B., Dyomin, A. G., Galkina, S. A., Saifitdinova, A. F., and Gaginskaya, E. R. 2017. Functional features of the nucleolar organizer in developing oocytes of juvenile birds. Russian Journal of Developmental Biology 48(3):224-230. https://doi. org/10.1134/S1062360417030031

Komissarov, A.S., Galkina, S. A., Koshel, E.l., Kulak, M. M., Dyomin, A. G., O'Brien, S. J., Gaginskaya, E. R., and Saifitdinova, A. F. 2017. New high copy tandem repeat in the content of the chicken W chromosome. Chromosoma. https://doi.org/10.1007/s00412-017-0646-5. 